\title{
Tekmeria
}

Vol $12(2014)$

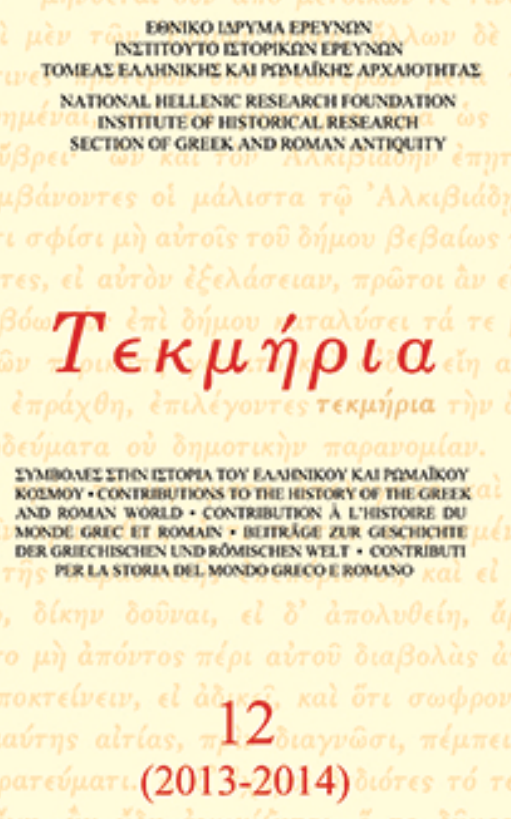

ATHEXS 2015

\section{Isiac Cults, Civic Priesthood and Social Elite in Hellenistic Demetrias (Thessaly): Notes on RICIS $112 / 0703$ and beyond}

Sofia Kravaritou

doi: $10.12681 /$ tekmeria.305

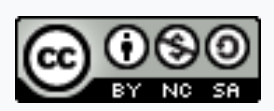

This work is licensed under a Creative Commons Attribution-NonCommercialShareAlike 4.0.

\section{To cite this article:}

Kravaritou, S. (2016). Isiac Cults, Civic Priesthood and Social Elite in Hellenistic Demetrias (Thessaly): Notes on RICIS 112/0703 and beyond. Tekmeria, 12, 203-233. https://doi.org/10.12681/tekmeria.305 


\section{SOFIA KRAVARITOU}

\section{Isiac Cults, Civic Priesthood and Social Elite in Hellenistic Demetrias (Thessaly): Notes on IGIX 2, 1107b (RICIS112/0703) and beyond*}

Following the decline of the Macedonian power and the abandonment of the basileion of Demetrias by its royal masters in the early second century BC, a Roman garrison was appointed in the city of Demetrias in $197 \mathrm{BC}$ and a community of Italians and Romans gradually formed and established itself in Eastern Thessaly. ${ }^{1}$ The shift from royal rulers to Romans encouraged the creation of the first Magnesian Koinon, as part of the generous policy of Flamininus towards Greek federal organization. However, this transitional phase of the first half of the second century $\mathrm{BC}$ instigated a turbulent period for local communities, which evidently suffered from internal tensions and contradictions. ${ }^{2}$ The fact that the Romans were not welcome by the entire population enabled the return of the Macedonians to Demetrias in 193 BC, for another twenty-five years; it was only

\footnotetext{
* I warmly thank the anonymous reviewers for very constructive criticism, as well as Prof. Bruno Helly and Dr. Richard Bouchon for reading a draft of the paper and offering helpful suggestions. I am grateful to Dr. Ilias Arnaoutoglou for instructive dialogue on the Thessalian associations and for letting me consult his unpublished paper on Isiac cult associations; also, Dr. Maria Stamatopoulou for sharing with me her knowledge on Demetrias and Dr. Mantha Zarmakoupi for correcting my English. All remaining errors are mine. Epigraphical publications are abbreviated after SEG.

1. B. Helly, "La Thessalie à l'époque romaine", in J. Cazeau et al. (eds.), Mémoires II (Mémoires du Centre Jean Palerne II, Saint-Étienne 1980) 37-50; id., "Les Italiens en Thessalie au IIe et au Ier s. av. J.-C.", in M. Cebéillac-Gervasoni (ed.), Les "bourgeoisies" municipales italiennes au Ile et Ier siècles av. J.-C. Centre Jean Bérard, Institut français de Naples, 7-10 décembre 1981. Colloques internationaux du CNRS no. 609 (Paris-Naples 1983) 355-380. Anthi Batziou-Efstathiou, Demetrias (Athens 2002) 13.

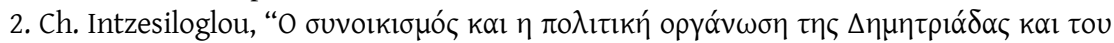

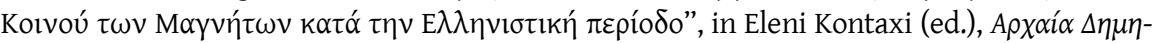

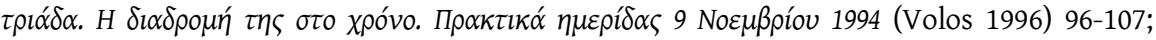
Batziou-Efstathiou, Demetrias (see n. 1) 13. Internal tensions in Demetrias: Livy 35.31, 1-16; cf. Sofia Kravaritou, "Imperial Cult, Greek Gods and Local Society in Demetrias (Thessaly)", in B. Takmer, E. Akdoğu Arca and N. Gökalp Özdil (eds.), Vir doctus Anatolicus. Studies in Memory of Sencer Şahin (Istanbul, in print) 600.
} 
after the battle of Pydna, in $168 \mathrm{BC}$, that Macedonians abandoned Demetrias and allowed the Romans and the second Magnesian Koinon to assume control over it. ${ }^{3}$

At that moment, the Romans most probably proceeded to distribute the former royal land to the Magnetes along with tax exemptions. ${ }^{4}$ Also, the Magnesian Koinon evidently instituted a large-scale administrative re-organisation covering the entire region of eastern coastal Thessaly; the presence of local independent communities named poleis and demes indicate the replacement of the concentric geopolitical model, which was previously imposed by the royal synoecism. ${ }^{5}$ Finally, a federal organization with common archons originating from all the poleis of the Koinon, who were appointed by a common assembly that most probably consisted of representatives of the cities-members of the Koinon and a synedrion, was likewise instituted and had Demetrias as its seat. ${ }^{6}$

This revival of local independent communities, whose history can be traced back at least to the Archaic and Classical periods, was followed by the contemporaneous revival of local traditional poliadic cults - a fact that is suggestive of the

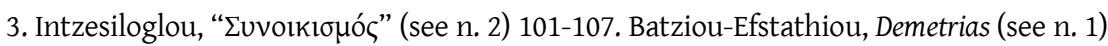
13-15.

4. Anthi Batziou-Efstathiou and Y. Pikoulas, "A Senatus Consultum from Demetrias", in Y. Pikoulas (ed.), Inscriptions and History of Thessaly: New Evidence. Proceedings of the International Symposium in Honour of Professor Christian Habicht (Volos 2006) 79-80.

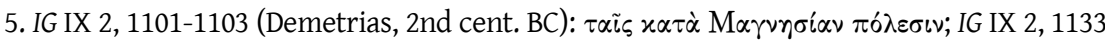
(Demetrias, 2nd cent. BC): $\dot{\eta} \pi \hat{\lambda}_{l \varsigma} \dot{\eta} \Delta \eta \mu \eta \tau \rho \iota \varepsilon ́ \omega v ;$ SEG 34 (1984) 553, 1l. 9-10 (Demetrias, 2nd cent. BC): ó $\tau \varepsilon \delta \tilde{\eta} \mu \circ \varsigma$ ó $\tau \tilde{\omega} \nu \Delta \eta \mu \eta[\tau \rho \iota \varepsilon ́ \omega \nu] ;$ IG IX 2, 1111, l. 1 (130-126 BC): ó $\delta \tilde{\eta} \mu \circ \varsigma^{\circ} \Sigma \pi \alpha-$ $\lambda \alpha u \theta \rho \varepsilon ́ \omega \nu$. On second century demotics and city ethnics: B. Helly, "Décrets de Démétrias pour les juges étrangers", BCH 95.2 (1971) 555, 1l. 7-9 (Decree of Demetrias located in Herakleia

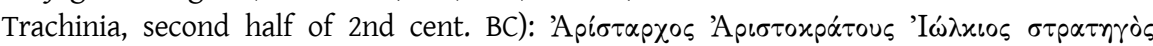

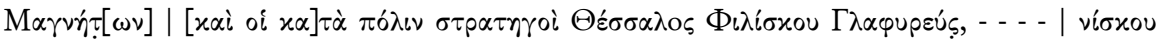

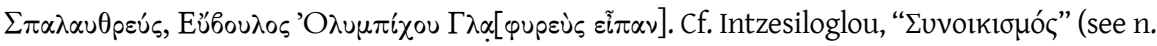
2) 101-107, figs. 1-3. On the second century evidence from Demetrias pertaining to demes, see Sofia Kravaritou, "Thessalian Perceptions of the Ruler Cult: 'Archegetai and Ktistai' from Demetrias”, in Paraskevi Martzavou and N. Papazarkadas (eds.), Epigraphical Approaches to the Post-Classical Polis. Fourth Century BC to Second Century AD. (Oxford Studies in Ancient Documents, Oxford 2013) 261-262, nn. 30, 33, 56.

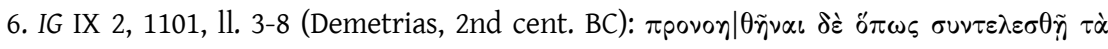

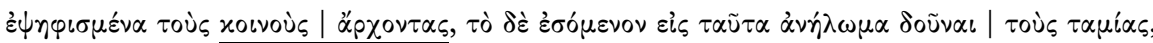

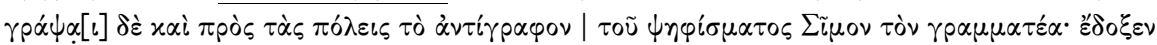

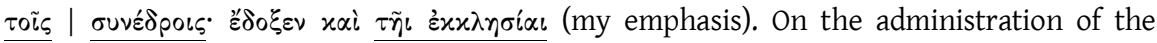

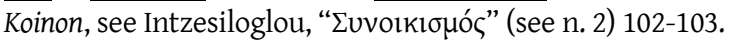


Isiac Cults, Civic Priesthood and Social Elite in Hellenistic Demetrias (Thessaly)

need for displaying a continuity of traditional civic identities from the middle of the second century BC onwards. ${ }^{7}$ In particular, three traditional local divinities were now declared tutelary divinities of the Magnesian Koinon; ${ }^{8}$ these were the cult of old Artemis Iolkia - the poliadic deity of the Classical city of Iolkos - which had been introduced in the agora of royal Demetrias, as well as the extra-urban cults of Zeus Akraios and Apollo Koropaios, both of which were worshipped in the area from at least the Archaic period onwards. ${ }^{9}$ The Isiac cults were also adapted into this new cultic landscape and found home in second century BC Demetrias, following their initial introduction into royal Demetrias during the third century BC.

This reorganisation of the religious life of Demetrias would surely have needed new funding sources. The end of royal euergetism towards local affairs from the second quarter of the second century $\mathrm{BC}$ onwards was followed by an interest in the display of euergetic behaviour on behalf of the Romans, as well as Greek individuals who also started performing acts of euergetism towards cult matters of their own city; at the same time, the city and the Koinon demonstrated a related interest in the public display of honorific attitudes towards them.

The aim of this paper is to shed light on this new model of civic-based euergetism towards local cult matters. The phenomenon will be discussed in relation to Isiac cults, focusing on the ways these cults adapted and operated in the new political, civic and sacred space, as well as into the new social and cultural environment of the second-century community of Demetrias. ${ }^{10}$

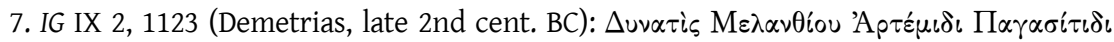

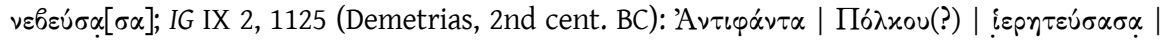

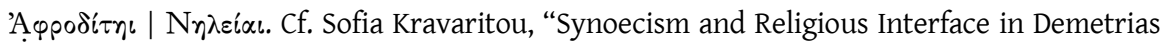
(Thessaly)", Kernos 24 (2011) 123.

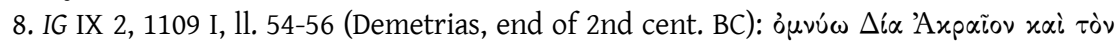

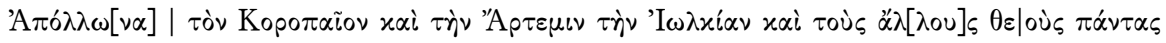
xai $\pi \dot{\alpha} \sigma \alpha$ s. Those divinities are also depicted on Hellenistic coins issued by the Koinon: E. Rogers, The Copper Coinage of Thessaly (London 1932) nos. 324-355. Cult processions to Apollo Koropaios and Zeus Akraios: IG IX 2, 1109; Heracleides (Pseudo-Dicaearchus) 2.8, ed. K. Müller, Geographi Graeci Minores I (Paris 1882, reprint of the first edition Paris 1855-1861) 107.

9. Kravaritou, "Synoecism" (see n. 7) 125-133.

10. On the term "Isiac cults", see L. Bricault, "Bilan et perspectives dans les études isiaques", in Enrichetta Leospo and Donatella Taverna (eds.), La Grande Dea tra passato e presente: Forme di cultura e di sincretismo relative alla Dea Madre dall'antichità a oggi (Tropi Isiaci I, Turin 2000) 91-96. 


\section{Isiac cults: the introduction and their milieu (third century BC)}

Early evidence on Isiac cults in Demetrias is provided by the mid third-century tombstone of Ouaphres, son of Horus, an Egyptian priest of Isis originating from Bousiris. ${ }^{11}$ It has been tentatively proposed that he could have been the founder of Isis' cult in Demetrias through his own private initiative, since it was customary for Egyptian priests to follow merchants' paths leading to Hellenistic cosmopolitan harbour cities. ${ }^{12}$

Specifically, epigraphic evidence for third-century Isiac cults implying the construction of cult facilities is already attested in Delos, Eretria, Thessaloniki another coastal royal foundation in Macedonia -, lately Rhamnous and Amphipolis, as well as Priene in Asia Minor. ${ }^{13}$ Furthermore, as in Demetrias, the earliest

11. RICIS 112/0701 (Demetrias, c. 250 BC). Cf. Maria Stamatopoulou, "Ouaphres Horou, an Egyptian Priest of Isis from Demetrias", in Donna Kurtz et al. (eds.), Essays in Classical Archaeology for Eleni Hatzivassiliou 1977-2007 (BAR 1796, Oxford 2008) 249-257, figs. 1-2; cf. J.-Cl. Decourt and A. Tziafalias, "Cultes et divinités isiaques en Thessalie: identité et urbanisation", in L. Bricault, M.J. Versluys and P.G.P. Meyboom (eds.), Nile into Tiber. Egypt in the Roman World. Proceedings of the IIIrd International Conference of Isis Studies, Leiden, May 11-14 2005 (Religions in the Graeco-Roman World 159, Leiden-Boston 2007) 337, fig. 1.

12. Stamatopoulou, "Ouaphres" (see n. 11) 252-254; cf. P.M. Fraser, "Two Studies in the Cult of Sarapis in the Hellenistic World", OpAth 3 (1960) 1-54. On Alexandrian merchants, id. Ptolemaic Alexandria I (Oxford 1972) 185-188; L. Bricault, "La diffusion isiaque: une esquisse", in P.C. Bol, G. Kaminski and C. Maderna (eds.), Fremdheit-Eigenheit. Ägypten, Griechenland und Rom. Austausch und Verständnis (Städel-Jahrbuch 19, Frankfurt am Main 2004) 548-556; cf. id., Les cultes isiaques dans le monde gréco-romain. Documents réunis, traduits et commentés (Paris 2013) 134-135.

13. Delos: IG XI 4, 1299 (RICIS 202/0101) (Late 3rd cent. BC); Ph. Bruneau, Recherches sur les cultes de Délos à l'époque hellénistique et à l'époque impériale (Paris 1970) 457-466. Eretria: IG XII, Suppl. 571 (RICIS 104/0103) (3rd cent. BC); Ph. Bruneau, Le sanctuaire et le culte des divinités égyptiennes à Éretrie (Leiden 1975) 104-105. Thessaloniki: E. Voutiras, "Sanctuaire privé-culte

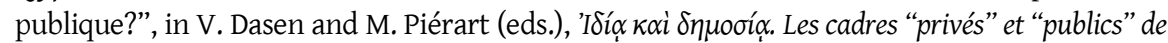
la religion grecque antique. Actes du IXe Colloque du CIERGA, Fribourg, 8-10 septembre 2003 (Kernos Suppl. 15, Liège 2005) 273-288; cf. C. Steimle, "Das Heiligtum der ägyptischen Götter in Thessaloniki und die Vereine in seinem Umfeld", in Corinne Bonnet, J. Rüpke and P. Scarpi (eds.), Religions orientales - culti misterici: Neue Perspektiven - nouvelles perspectives - prospettive nuove (Stuttgart 2006) 27-38. Rhamnous: IRhamnous 59 (RICIS Suppl. 101/0502); I. Arnaoutoglou, "Group and Individuals in IRhamnous 59 (SEG 49.161)", in J.-Chr. Couvenhes and S. Milanezi (eds.), Individus, groupes et politique à Athènes de Solon à Mithridate. Actes du Colloque International, Tours, 7 et 8 mars 2005 (Tours 2007) 315-337. Amphipolis: R. Veymiers, "Les cultes 
Isiac Cults, Civic Priesthood and Social Elite in Hellenistic Demetrias (Thessaly)

evidence for the cult of Isis in Delos and Eretria is associated with individuals of Egyptian origin, while at Piraeus Egyptian merchants had already received public permission to build a sanctuary devoted to Isis. ${ }^{14}$ In that perspective, the Isiac cults introduced at Thessaloniki, at approximately the end of the fourth/beginning of the third century $\mathrm{BC}$, could provide a useful insight into contemporary maritime links with Alexandria of Egypt and some of the above mentioned harbours in Greece, like Delos. ${ }^{15}$ In that respect, although the conditions behind the emergence of Isis' cult in Demetrias remain obscure, the contemporary presence of Egyptians in Demetrias indicates that the first of a local cultic community most probably developed within the restricted framework of a cultic association; however, no material evidence arguing for the presence of cultic facilities is preserved on a local level. ${ }^{16}$

Furthermore, it is also widely held that sacred space and the ritual landscape of these cults originated from Egypt eventually flourished within the mixed resident communities of the Hellenistic cosmopolitan harbour cities and were always open to foreign devotees. ${ }^{17}$ Thus, it has been proposed that the third-century cult of Isis in Demetrias would have also included Greeks, especially soldiers of the Macedonian

isiaques à Amphipolis. Membra disjecta (IIIe s. av. J.-C. - IIIe s. apr. J.-C.)”, BCH 133 (2009) 475481, figs. 1-5. Priene: IPriene 195 (c. 200 BC).

14. Cf. n. 13; Piraeus: IG II 337 (IG II ${ }^{3}$ 1, 337; RICIS 101/0101) (333/2 BC). Cf. Bricault, "Diffusion" (see n. 12) 548; id., Cultes isiaques (see n. 12) 170-180.

15. Following the placement of the Sarapieion into the Hippodamian plan, M. Vitti ("Per una definizione dell'impianto urbano di Salonicco da Cassandro a Galerio", Faventia 14.2 [1992], 55-85) suggested its foundation at 316 BC; cf. Voutiras, "Sanctuaire" (see n. 13) 275: "chronologiquement proche de la fondation de la cité elle-même (sous le règne de Cassandre, probablement à son début en 316 ou en 315 av. J.-C) ”. For the earlier cult elements into the third century BC, see L. Bricault, Atlas de la diffusion des cultes isiaques (IVe s. av. J.-C. - IVe s. ap. J.-C.) (Mémoires de l'Académie des Inscriptions et Belles-Lettres 23, Paris 2001) 22; id., "Fonder un lieu de culte", Mediterranea 4 (2007) 52. On Roman mobility from Delos to Eretria and Thessaloniki, see Paraskevi Martzavou, "Les cultes isiaques et les Italiens entre Délos, Thessalonique et l'Eubée”, Pallas 84 (2010) 181-205.

16. Detailed epigraphic evidence in Decourt and Tziafalias, "Cultes" (see n. 11) 338-343. Stamatopoulou, "Ouaphres" (see n. 11) 254; cf. Françoise Dunand, Le culte d'Isis dans le bassin oriental de la Méditerranée III. Le culte d'Isis en Asie Mineure. Clergé et rituel des sanctuaires isiaques (Leiden 1973) 4-17, 53-61, 83-105.

17. J. Mylonopoulos, "The Dynamics of Ritual Space in the Hellenistic and Roman East", Kernos 21 (2008) 66. 
army who had served in Egypt. ${ }^{18}$ Furthermore, the onomastics on the grave stelai of Demetrias offer further signs of local linguistic and social interaction between Greeks and Egyptians that could give some insight into the presence of a local multicultural cultic community. In this perspective, Egyptians bearing Greek names are thought to belong to Hellenized Egyptian families of Demetrias, while it is already argued that Greek names of Egyptian inspiration reflect links between Greek families and Egyptians. ${ }^{19}$ Although the potential presence of bilingual individuals or intermarriages between Egyptians and Greeks and how these may have impacted upon the ethnic and cultural identity of both sides are issues open to question, the mutual interchange of cultural influences, which is reflected in the onomastics of the city, shows that Egyptian and Greek residents of Demetrias could be - by cultural interference - a quite unified and dynamically developed body of cult-participants in the local Isiac cults. Furthermore, the numerous epigraphically attested Phoenicians originating from Askalon, Sidon, Tyre, Arados, Kition, etc., who were properly settled in Demetrias, might have naturally grown accustomed to Isiac cults in their places of origin. ${ }^{20}$

Isiac cults: civic patronage and private associations (second century $\mathrm{BC}$ )

In the late second century $\mathrm{BC}$, epigraphic evidence provides further information about the local cult of the Isiac divinities which became now an official polis cult in Demetrias. An honorific inscription dated around $117 \mathrm{BC}$ preserves the proposal and resolution issued by a local religious association - the koinon of the hypostoloi-, with the aim of granting honours to a local benefactor, Kriton son of Kriton, the

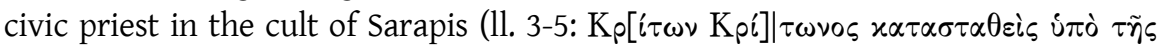

18. Dunand, Culte (see n. 16) 49-50; Decourt and Tziafalias, "Cultes" (see n. 11) 337. Stamatopoulou, "Ouaphres" (see n. 11) 254.

19. Cf. Sofia Kravaritou, "Sacred Space and the Politics of Multiculturalism in Demetrias (Thessaly)", in Milena Melfi and Olympia Bobou (eds.), Hellenistic Sanctuaries. Between Greece and Rome (Oxford, in print); the epigraphic evidence from Demetrias tombstones in Decourt and Tziafalias, "Cultes” (see n. 11) 337-342; also, Maria Stamatopoulou, “The 'Banquet' Motif on the Funerary Stelai of Demetrias", in Catherine M. Draycott and Maria Stamatopoulou (eds.), Dining and Death. Interdisciplinary Perspectives on the 'Funerary Banquet' in Ancient Art, Burial and Belief. Proceedings of the International Conference, Oxford, September 2010 (Leuven, in print).

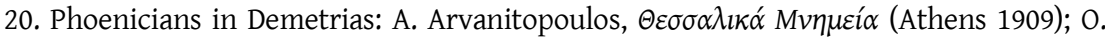
Masson, " Recherches sur les Phéniciens dans le monde hellénistique ", BCH 93.2 (1969) 689696. Cf. Corinne Bonnet, Les enfants de Cadmos. Le paysage religieux de la Phénicie hellénistique (De l'Archéologie à l'Histoire 63, Paris 2014). 


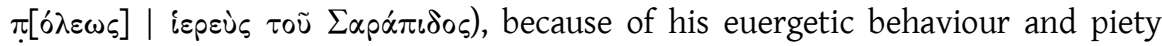
towards the divinities and the hypostoloi themselves respectively (ll. 12-13: s's $\tau \varepsilon$

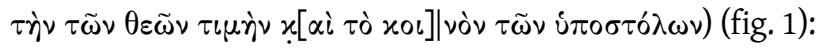

21. IG IX 2, 1107b (RICIS 112/0703) (Demetrias, c. 117 BC); cf. Decourt and Tziafalias “Cultes" (see n. 11) 349-350, fig. 10. Translation adapted from L. Bricault, Recueil des inscriptions concernant les cultes isiaques (RICIS) (Mémoires de l'Académie des Inscriptions et Belles-Lettres 31, Paris 2005) 127. 
Trans. "The hypostoloi proposed: since Kriton, son of Kriton, priest of Sarapis appointed by the city, acted towards all matters concerning the Gods in a manner worthy of both his personal excellence and that of his city, without neglecting anything in order to show his eagerness and philotimia; and since, with respect to the therapeutai, he has not ceased to act with magnificence and willingness; and, in his desire to make his good intentions memorable, he granted, for both the Gods and the koinon of the hypostoloi, from his personal resources, a thousand silver drachmas intended, during the annual meeting of the hypostoloi, by spending the product of the interest (of this account of money), to embellish even more the honours bestowed upon the Gods and allow the hypostoloi to enjoy for ever the appropriate benevolence; for these reasons, it seemed appropriate to the hypostoloi, to crown Kriton, son of Kriton, with a golden crown and (honour him with) a painted portrait and allow him to share for his entire life the benefits granted to those disposed with benevolence towards the hypostoloi, while his crowning will take place perpetually in all meetings of the hypostoloi in the sanctuary; and (it also seemed appropriate) to erect this decree and (set) the crown in the most prominent place of the Sarapieion, where also his portrait must be placed, with the following inscription: "the hypostoloi (honour) Kriton, son of Kriton, for his virtuousness and goodwill towards themselves and for his piety to the divinity".

\section{Private groups associated with the local Isiac cults}

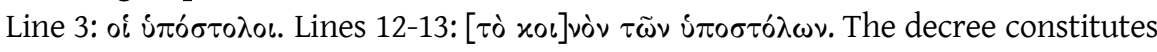
the first testimony for the presence of a group of hypostoloi in both Demetrias and the whole of Thessaly. The koinon of the hypostoloi associated with the Sarapieion of Demetrias is the proposing body and issuing authority of this honorific decree bestowing honours (lines 19-20: the setting of a crown and a painted portrait) upon the civic priest of Sarapis, as well as of the honorific inscription accompanying them in the Sarapieion, which is originally prefigured, in lines $28-30$. This unusual opening, which indicates the ability of the group to bring forward a proposal and ratify it, is attested twice in third century Demetrias: for Iolkos, one of the most important synoecized communities, and for the astynomoi of Demetrias. ${ }^{22}$ It hints at the considerable size and importance of the group of hypostoloi within the local

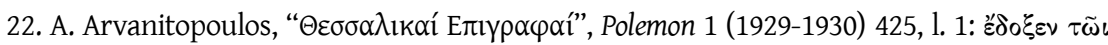

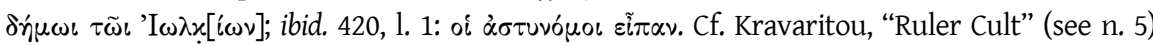
267-269. 
Isiac Cults, Civic Priesthood and Social Elite in Hellenistic Demetrias (Thessaly)

socio-political context and also at the wide acceptance of Kriton's beneficence. The association obviously displayed organized corporate activity which had common affairs to be administered since, apart from the fact that they decided as a collective authority to grant honours to a civic official, they were also holding regular annual

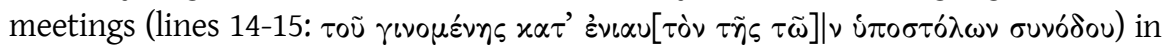
the civic Sarapieion. Always consecrated to the ritual performance of the Isiac cults, associations of hypostoloi are well known in other Hellenistic cities. They are usually known to have honoured civic priests or other members of religious personnel for euergetic acts towards them and the Isiac cults. For example, in first-century BC Amphipolis, the local hypostoloi along with the priest Apollodoros crowned the trierarchos Aulos, a member of the cult personnel in the cultic activities devoted to Isis. Also, earlier, in third-century BC Eretria, the local koinon of hypostoloi, along with that of melanephoroi, crowned "priest Phanias, son of Jason, the hereditary priest in the Isiac cults, according to the divine oracle. ${ }^{23}$ The koinon of melanephoroi, or simply melanephoroi, is also widely attested on Delos and was also exercising organized group activity within the frame of the local Isiac cults; ${ }^{24}$ they displayed honorific attitudes towards civic priests that were similar to those of the hypostoloi and equally held communal meetings (synodoi). ${ }^{25}$ Following the thesis originally defended by F. Poland and eventually accepted by Françoise Dunand and M.-F. Baslez, it is now generally believed that the melanephoroi were among several associations of priestly personnel involved in the organization and performance of

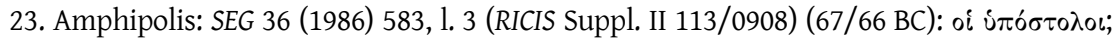
cf. Veymiers, “Amphipolis" (see n. 13) 485-486, fig. 8. Eretria: IG XII Suppl. 571 (RICIS 104/0103)

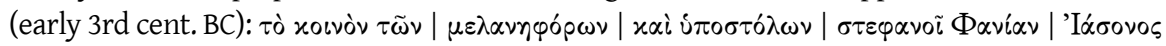

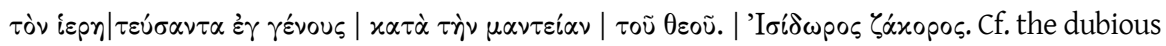
case in Philippi related to Thea Almopia: SEG 50 (2000) 618 II, 1l. 9-11 (3rd cent. AD):

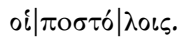

24. For example, IG XI 4, 1226 cr. 2, ll. 2-4 (RICIS 202/0135) (Delos, Sarapieion B, early 2nd

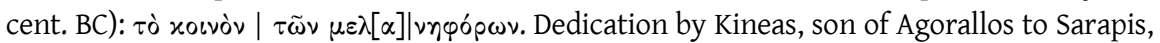
Isis, Anoubis; also, ID 2076, l. 1 (RICIS 202/0260) (Delos, Sarapieion C, 123/2 BC): oi $\mu \varepsilon \lambda \alpha-$

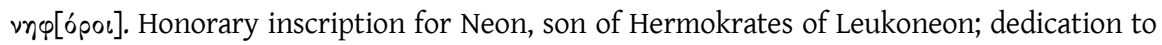
Sarapis, Isis, Anoubis and Harpokrates.

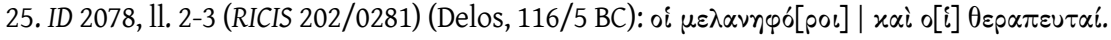
Honorary inscription for the priest Dionysios, son of Dionysios, of Sphettos; dedication to Sarapis, Isis, Anoubis and Harpokrates. ID 2075, 1.1 (RICIS 202/0257) (Delos, Sarapieion C,

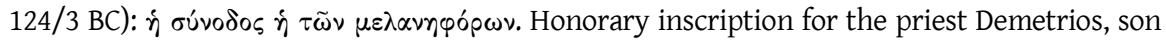
of Hermesion of Marathon; dedication to Sarapis, Isis, Anoubis. 
cult activities in the sanctuaries devoted to Isiac divinities. ${ }^{26}$ Judging from their name, which is etymologically related to the colour black, L. Bricault identified them as an association of devotees charged with the ritual representation of the mourning of Isis for the loss of Osiris during religious processions ${ }^{27}$ In contrast, the hypostoloi were originally considered by Ph. Bruneau to refer to those members of the priestly personnel attached to the Isiac cults, who wore a long white loincloth of Egyptian type - similar to the priestly personnel of Isiac cults depicted in the frescoes of Herculaneum, which represent Isiac ceremonies in front of a temple. ${ }^{28}$ Currently, this has become the prevailing opinion on the ritual identity of the hypostoloi. ${ }^{29}$ Another interpretation that identifies them as assisting personnel (hypo-) helping with the dressing (stolos) of the divine statue, a ritual at which a stolistes or an archistolos would have presided, seems quite tentative and is actually outdated. ${ }^{30}$

Line 9: $\theta \varepsilon \rho \alpha \pi \varepsilon u \tau \alpha$ s. The decree constitutes also the first proof for the presence of a group of therapentai in both Demetrias and the entire Thessaly. It denotes the existence of groups of worshippers forming a society devoted to the daily service of the Sarapieion, while also assisting the priesthood during cult festivities. ${ }^{31}$

Groups of therapeutai are also present in many parts of the Hellenistic world. In Delos, the therapeutai in the local Isiac cults are also favoured with the euergetic acts of the local priesthood along with other groups of devotees, such as the local melanephoroi or the Sarapiastai. ${ }^{32}$ In this respect, there is epigraphic evidence attesting to their favourable responses to benevolent civic priests, in which they

26. F. Poland, Geschichte des griechischen Vereinswesens (Leipzig 1909) 43; Dunand, Culte (see n. 16) 25-26; M.-F. Baslez, “Une association isiaque: les Mélanéphores”, ChrÉg 50 (1975) 299-300; ead., "Les associations à Délos: depuis les débuts de l'Indépendance (fin du IVe siècle) à la période de la colonie athénienne (milieu du Ile siècle)", in P. Fröhlich and $\mathrm{P}$. Hamon (eds.), Groupes et associations dans les cités grecques (IIIe siècle av. J.-C. - IIe siècle apr. J.-C.). Actes de la table ronde de Paris, INHA, 19-20 juin 2009 (Hautes Études du monde gréco-romain 49, Paris 2013) 239-240.

27. L. Bricault, "Associations isiaques d'Occident", in A. Mastrocinque and C. Giuffre Scibona (eds.), Demeter, Isis, Vesta and Cybele. Studies in Greek and Roman Religion in Honour of G. Sfameni Gasparo (Stuttgart 2012) 91-104.

28. Bruneau, "Sanctuaire" (see n. 13) 73-75, 112-114.

29. M. Malaise, "Les hypostoles. Un titre isiaque, sa signification et sa traduction iconographique”, ChrÉg 82 (2007) 302-322.

30. Ibid. 304-309, with detailed bibliography.

31. Baslez, "Associations" (see n. 26) 244-247.

32. For example, ID 2039, 11. 2-3 (RICIS 202/0352) (Delos, Sarapieion C, c. 93/2 BC): x $\alpha i]$ $\mu \varepsilon \lambda \alpha \nu[\eta] \varphi o_{p o s \varsigma}$ xai | $\theta \varepsilon \rho \alpha \pi \varepsilon u \tau \alpha \tilde{\iota} \varsigma$. Dedication by the priest Dikaios, son of Dikaios of Ionidai. 
Isiac Cults, Civic Priesthood and Social Elite in Hellenistic Demetrias (Thessaly)

display publicly an eventual honorific attitude towards them. ${ }^{33}$ Similar honorific attitudes were also displayed by the local therapeutai in Maroneia, in Northern Greece. $^{34}$ In addition, Delian therapeutai demonstrated an euergetic stance, occasionally along with the Isiac priests, by contributing money for the construction or renovation of public - usually cultic - buildings, ${ }^{35}$ as well as by erecting votive monuments to the gods, unaccompanied or together with other cultic associations. ${ }^{36}$ Furthermore, besides Isiac cults, groups of therapeutai are also attested in relation to Asklepios' cult in Athens, oriental cults on Delos, as well as various cults in Asia Minor. ${ }^{37}$ The Delian therapeutai use the self-descriptive term "koinon" in their records of honorific or votive inscriptions, in which they usually act in co-operation with other cultic groups; yet, they do not seem to be in possession of an administrative mechanism capable of supporting further associative life. As a result, therapeutai was identified by Vidman as a term describing "a loose association". ${ }^{38}$ However, new evidence challenges his interpretation, since the therapeutai from Maroneia display a structured associative life, without making use of the self-descriptive term of koinon. ${ }^{39}$ In addition to issuing honorific decrees for Isiac civic priests, they held regular meetings (synodoi) that were presided over

33. ID 2077, 11. 1-2 (RICIS 202/0269) (Delos, 119/8 BC or a little later): oi $\mu[\varepsilon \lambda \alpha] v \eta \varphi[o ́ p o r$ $\varkappa] \alpha i$ oi $\theta \varepsilon \rho \alpha \mid \pi \varepsilon v \tau \alpha i$. Honorary inscription for the priest Dionysios, son of Menios of Paiania; dedication to Sarapis, Isis, Anoubis and Harpokrates.

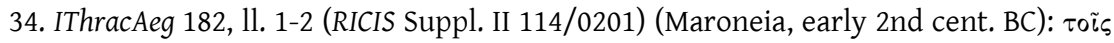

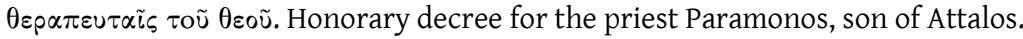

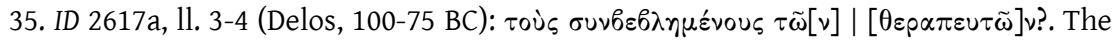
priest and the therapeutai contribute for the reconstruction of the hydreion.

36. IG XI 4, 1226 cr. 1, 11. 2-4 (RICIS 202/0135) (Delos, Sarapieion B, early 2nd cent. BC): $\tau \grave{o}$

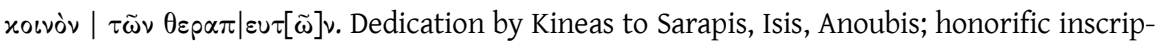
tions for Kineas issued by the koina of therapeutai and melanephoroi, as well as the thiasos of Sarapiastai.

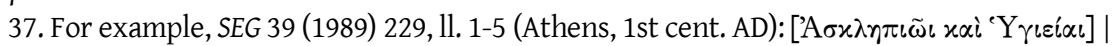

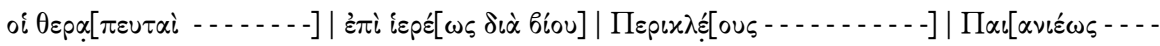

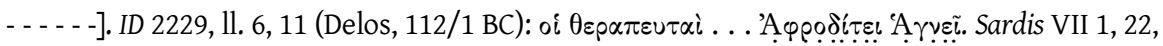

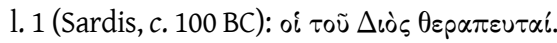

38. L. Vidman, Isis und Sarapis bei den Griechen und Römern: Epigraphische Studien zur Verbreitung und zu den Trägern des ägyptischen Kulten (Religionsgeschichtliche Versuche und Vorarbeiten 29, Berlin 1970) 69.

39. IThracAeg 183, 1l. 7-8 (RICIS Suppl. 114/0203) (Maroneia, 2nd cent. BC): oi $\theta \varepsilon \rho \alpha \pi \varepsilon u \mid \tau \alpha i$

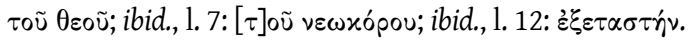


by their own appointed officials. ${ }^{40}$ Therefore, as I. Arnaoutoglou proposes in a forthcoming publication, "in the current state of evidence it is impossible to present a coherent account about the different groups of therapeutai" and therefore "therapeutai cannot be treated in a uniform manner". ${ }^{4}$

Returning to Demetrias, the honorific inscription issued by the association of the hypostoloi offers, as Arnaoutoglou points out, "a clear cut distinction between them and therapeutai". ${ }^{42}$ It should be also noted that, in this particular case, the members of the local koinon of the hypostoloi put themselves in charge of the honours displayed towards the civic priest of Sarapis for his benevolent attitude (line 29: sù [oi as]), both towards them and the local therapeutai. The latter are simply mentioned (line 9: $\theta \varepsilon p \alpha \pi \varepsilon v \tau \dot{\alpha} \varsigma)$, but - unlike the evidence from Delos and Maroneia - they do not participate actively in the corporate act of displaying gratitude to civic magistrates publicly. ${ }^{43}$ In this light, and in the absence of other local evidence from Demetrias or the entire Thessalian region attesting further corporate organization, the therapeutai frequenting the Sarapieion of Demetrias seem to fit the definition of "parishioners" a term recently proposed by Bricault, in order to describe those devotees attached to sanctuaries in a permanent way, who did not have any especially appointed role in the ritual performance of the local Isiac cults. ${ }^{44}$

In regard to the ethnic and cultural origin of the people who joined those second century BC groups or frequented the sanctuaries related to the Isiac cults, apart from the Egyptians and the Greeks from mainland Greece, epigraphical evidence from Delos refers, for example, to local melanephoroi originating from the cities of the Seleucid Empire, such as Antioch and Seleucia. ${ }^{45}$ Their presence confirms the multicultural background and the ecumenical character of the ideology and ritual performance of the Isiac cults.

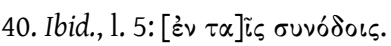

41. I. Arnaoutoglou, "Koinon Isiastan Sarapiastan. Isiac Cult Associations in the Eastern Mediterranean", in V. Gasparini and R. Veymiers (eds.), The Agents of Isiac Cults. Identities, Functions and Modes of Representation. Proceedings of the VIth International Conference of Isis Studies (Erfurt, May 6-8 2013-Liège, September 23-24 2013)(Leiden-Boston, forthcoming). I am grateful to the author for letting me consult his unpublished manuscript.

42. Arnaoutoglou, "Koinon" (see n. 41).

43. Cf. nn. 32-35.

44. RICIS (see n. 21) 203.

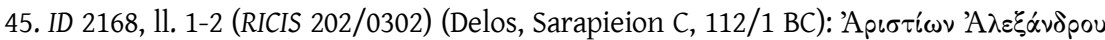

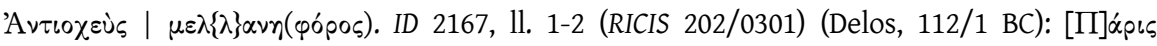

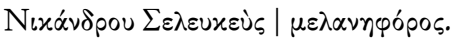


Specifically, with regard to the origin of the devotees of the Isiac cults in the Sarapieion of second century Demetrias, local inscriptions do not provide evidence on the ethnic and cultural background of the local therapeutai and hypostoloi; however, taking into consideration the evidence from other cities, it can be inferred that members of the Hellenized Egyptian families of Demetrias, members of the local Greek families who developed family ties with Egyptians through intermarriages, as well as the numerous individuals originating from the cities of the Seleucid Empire whose presence is attested in Demetrias, provide the best candidates for the composition of these local private associative groups. ${ }^{46}$ In addition, the presence of local Isiac groups would surely highlight those among the Greeks - citizens of Demetrias or other Greek cities - who by this period had become accustomed to and turned to such divinities for comfort and salvation in everyday life and the afterlife, as well as foreign individuals - merchants, soldiers, sailors, etc. - passing by or making short stays in Demetrias. Egyptian Isis, protector of sailors and of nautical activities, along with the - also locally attested - Phoenician Atargatis, were both usually worshipped in maritime areas and would have been perfectly adapted to the natural landscape of Demetrias' port-city ${ }^{47}$ Egyptians, but also Phoenicians, would usually address themselves to those syncretic deities expressing cross-cultural features. ${ }^{48}$

In conclusion, the Sarapieion of Demetrias was in all probability frequented by a large and culturally diverse milieu of devotees, who participated in the organization and the performance of the multiple and sumptuous ritual activities performed for the Isiac divinities.

46. Cf. nn. 19-20.

47. Isis: Ph. Bruneau, “Isis Pélagia à Délos ”, BCH 85 (1961) 435-446; id., "Isis Pélagia à Délos (Compléments)”, BCH 87 (1963) 301-308. L. Bricault, Isis, Dame des flots (Aegyptiaca Leodensia 7, Liège 2006). Atargatis: Luc. Syr. D. ; Bruneau, Recherches (see n. 13) 467; IG XII 3 , 104 (Nisyros). Both divinities were often assimilated into other Greek, Anatolian or Phoenician feminine deities - Artemis, Aphrodite, Demeter, Hera, Cybele and Astarte - and were qualified with protective functions towards maritime activities along Greek and Phoenician coasts: see Eratosth. Catasterismoi 9; Plut. Crass. 17; Luc. Syr. D. 31-32; cf. Corinne Bonnet, "Le roi et la déesse. À propos de la dédicace grecque à Ptolémée et Aphrodite de la grotte de Wasta, près de Tyr", SEL 21 (2004) 125-140, esp. 134-135: Aphrodite Epekoos assimilated to Astarte and Isis at Tyre (2nd cent. BC).

48. See, for example, the bilingual Greek-Phoenician dedication to Aphrodite Pontia Astarte "for the sake of all sailors", in SEG 55 (2005) 936 (IG XII 4, 546) (Kos, last quarter of the 4th cent. BC). Cf. Stéphanie Paul, Cultes et sanctuaires de l'île de Cos (Kernos Suppl. 28, Liège 2013) 91-92; ID 2132 (RICIS 202/0365) (Delos, Sarapieion, 115/4 BC after ID; 2nd-1st cent. BC following RICIS): Votive of a Sidonian to "Isis Soteira Astarte Aphrodite Euploia". 


\section{The Sarapieion}

The original second-century BC cult site of the Sarapieion of Demetrias remains unidentified and is yet to be located. ${ }^{49}$ Remains of the stone foundations of a large scale intra-muros building with a peribolos and many stone pedestals, along with a stone stele with traces of Harpokrates' name and a marble statuette of Isis (?) holding Harpokrates (?) or Horus (?) were discovered at the beginning of the twentieth century on the southern edges of the city inside the fortification walls, on the northern flank of the hill of Prophet Elias, and were tentatively attributed by the excavator, A. Arvanitopoulos, to a cult of Harpokrates (fig. 2). At the same time, Arvanitopoulos had already identified with the Sarapieion of Demetrias the important ruins he excavated on the hill of the site he had named "Kato Akropolis", a complex building which later turned out to be the Macedonian Anaktoron of Demetrias. ${ }^{50}$ The findspot of the building located nearby Prophet Elias' hill - intramuros and towards the edge of the urban space - might fit with the usual location of the Isiac cult places, while the neighbouring stream of Aligarorema could have provided the cult with water facilities and a virtual Nilotic landscape, the par excellence element of its original sacred space. ${ }^{51}$ Although detailed publication of the excavated material is still missing, those details could support an eventual identification with the public sanctuary of the Sarapieion or with a second cult place - a private one? - devoted to the Isiac cults. It is evident that the history of the site requires further investigation.

It seems that the local cult of the Isiac divinities, from the mid third century BC onwards, gained much importance over time, thus its premises had outgrown their original designated space - a phenomenon that finds parallels in many other second-century $\mathrm{BC}$ communities. ${ }^{52}$ The cult has become public and the fact that

49. Cf. Fr. Stählin, E. Meyer and A. Heidner, Pagasai und Demetrias. Beschreibung der Reste und Stadtgeschichte (Berlin 1934) 188; P. Marzolff, “Die Bauten auf Höhe 84 ('Heroon'-Höhe)”, in S.C. Bakhuizen, F. Gschnitzer, Chr. Habicht and P. Marzolff (eds.), Die deutschen archäologischen Forschungen in Thessalien. Demetrias V (Bonn 1987) 39. Decourt and Tziafalias, "Cultes" (see n. 11) 349-350.

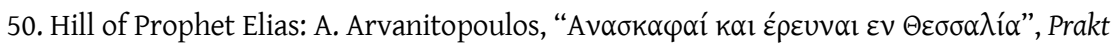
(1915) 130-200, especially 160-161; cf. Decourt and Tziafalias, "Cultes” (see n. 11) 349. Hill of

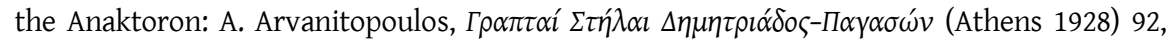
fig. 102 (" $\Sigma$ ").

51. On Nilotic landscapes: Apul. Met. 11.20; cf. Bruneau, Recherches (see n. 13) 457-480; Mylonopoulos, "Dynamics” (see n. 17) 64.

52. Bricault, "Diffusion” (see n. 12) 548-556. 
the second century BC priestly office was held by a Greek points to the adaptation of the cult by the indigenous people - a cult that was originally filtered through the Ptolemaic ideology and developed along with the ecumenical needs of the Greek cosmopolitan harbour cities with mixed-resident communities..$^{53}$ The official cult seat, with which the local, presumably multicultural, koinon of hypostoloi and the therapeutai were associated, argues in favour of the adoption of the Isiac cults by a dynamically growing local body of devotees who actively participated in the local Isiac cults displaying corporate activities - participation in the ritual, honorific attitudes - towards the Isiac divinities and their priests. In fact, the resolution of the hypostoloi indicates that this cult building served also as an area of public display of inscribed collective decisions or honorific monuments erected on behalf of private associations of religious nature. Unfortunately, apart from this decree which attests to the presence of a civic priest and of associative groups of devotees of low or higher corporal intensity, no other document is known to-date that could inform us about the daily running of the sanctuary.

Who was/were the divinity/(-ies) honoured in the public Sarapieion of Demetrias? Although the name of the sanctuary points to Sarapis, the reference

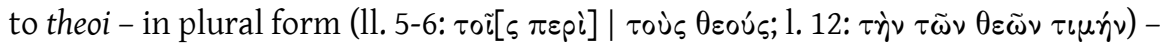
hints at the presence of many Isiac cult receptors. This hypothesis could be supported by some other finds located in Demetrias, such as a Hellenistic drinking cup bearing the graffito I $\Sigma \mathrm{I} \Delta \mathrm{I}$, a late Hellenistic votive inscription to Isis, Serapis and Anubis and a contemporary or later one dedicated to Sarapis and Isis. ${ }^{54}$ of course, there could have been more than one sanctuaries devoted to Isiac divinities, but it seems that the Sarapieion was of primary importance to the social but also political life of the city.

53. Dunand, Culte (see n. 16) 77-78.

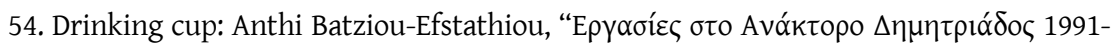

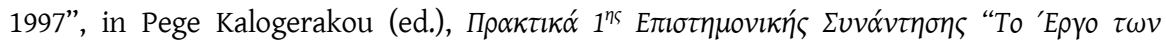

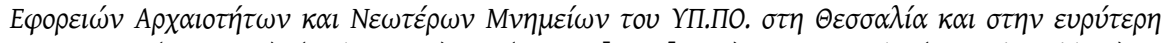

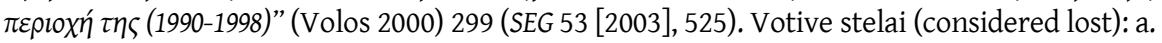

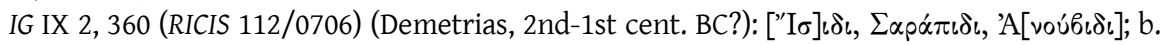
L. Robert, "Inscriptions de Thessalie", in Hellenica. Recueil d'épigraphie, de numismatique et d'antiquités grecques I (Paris 1940) 66-67, no. 1 (RICIS 112/0705) (Demetrias, 2nd-1st cent. BC?):

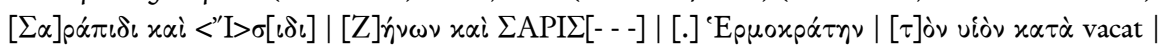
$[\pi] \rho \circ \sigma \tau \alpha \gamma \mu \alpha$. Following the new reading (1. 2: [Z]'́n $\omega \nu \nu \mathrm{K} \alpha i \sigma \alpha \rho \circ \varsigma[\dot{\alpha} \pi \varepsilon \lambda(\varepsilon \dot{v} \theta \varepsilon \rho \circ)])$ in Decourt and Tziafalias, "Cultes" (see n. 11) 354 (RICIS Suppl. 112/0705), the inscription was dated to the Imperial period. 
Contemporary epigraphic evidence reveals it to have been one of the civic sanctuaries - besides those of the three tutelary divinities - that officially served in the publication of the decrees emanating from the federal administration of the local Magnesian Koinon. This is indicated, for example, by a second-century decree that was issued jointly by the federal Council and the common Assembly of the Koinon. ${ }^{55}$

Consequently, the second century BC Sarapieion, which was instituted by the polis of Demetrias, constituted a shared place for displaying corporate religious, euergetic and eventually honorific activity between diverse levels of social and political organization of both public and private order - civic and federal -, as well as associative respectively. These attitudes transformed the sanctuary from a simple cult space to a symbol of high social and political prestige within the civic and sacred space of Demetrias.

\section{Civic Sarapieion, private donations and the construction of social prestige}

The local private association of hypostoloi, participating actively in the performance of the Isiac cult activities, praised the civic priest Kriton for his benefactions towards cult matters of the local Isiac cults. According to their resolution, Kriton donated the considerable amount of "one thousand drachmas destined to embellish even more the cult ceremonies in honour of the Gods" (ll.

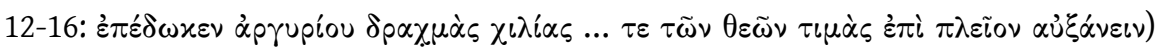
and "allow the hypostoloi to enjoy for ever the appropriate benevolence" (11. 17-18:

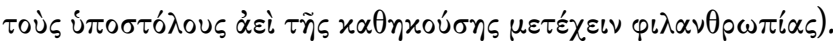

The signifier used to describe the act of Kriton's donation is the verb epedoken. This verb was originally involved in the procedure of public subscriptions (epidoseis) developed in the public life of Greek cities from the Classical period onwards. ${ }^{56}$ The epidosis originally constituted a technically voluntary contribution to state revenues, or sometimes a compulsory tax applied particularly in times of political and social crisis - for example in war - that usually followed an initial appeal for funds on

55. IG IX 2, 1101, 11. 1-3 (RICIS 112/0702) (Demetrias, 2nd cent. BC): [- - . - . - . - .

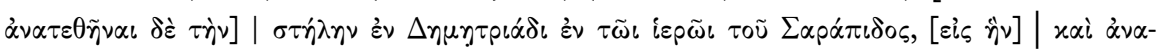

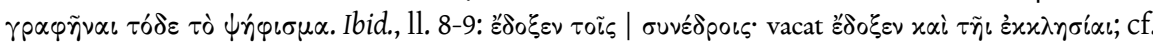

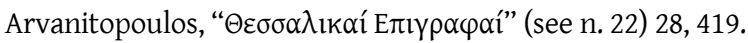

56. L. Migeotte, Les souscriptions publiques dans les cités grecques (Quebec 1992); cf. recently, A. Chaniotis, "Public Subscriptions and Loans as Social Capital in the Hellenistic City: Reciprocity, Performance, Commemoration", in Paraskevi Martzavou and N. Papazarkadas (eds.), (see n. 5) 89-106, esp. 90-91. 
Isiac Cults, Civic Priesthood and Social Elite in Hellenistic Demetrias (Thessaly)

behalf of the city. ${ }^{57}$ Through the establishment of procedures completely open to the public, the administrative body of the polis, on special occasions, used to appeal, discuss, encourage, approve or reject and finally receive contributions of money on behalf of wealthy citizens. ${ }^{58}$ This money was destined to communal purposes, such as the purchase of grain for the local population, the erection of defensive constructions during a time of war, or later, in the Hellenistic period, the construction of public buildings, the raising of money for cult purposes, etc. ${ }^{59}$ The verb epedoken, apart from describing the act of a citizen contributing money to an epidosis, was also used to describe an oral promise by someone to realize a contribution during the common assembly discussing the epidosis, regardless of the eventual achievement or failure of the original promise..$^{60}$ In the case of Kriton, it seems that he had already contributed the money, for which he received the honours on behalf of the hypostoloi. However, the text provides no evidence that could argue for the organization of a public subscription in Demetrias, with the aim to pursue material support for the Isiac cults, in which Kriton could have made his contribution.

Furthermore, the money coming from Kriton's donation was not to be spent right away for the purposes of the cult. The capital of the donation ought to be lent out on interest and the interest would have been eventually used to the

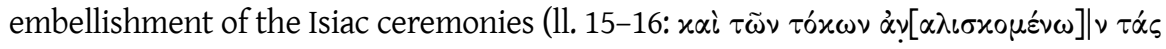

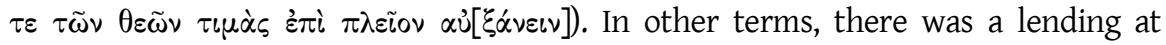
interest (egdaneismos) of the money that was originally planned in Kriton's donation. ${ }^{61}$ Therefore, the actual practice of the cult would cost nothing to the

57. Chaniotis, "Public Subscriptions" (see n. 56) 93-95; cf. K. Harter-Uibopuu, "Money for the Polis. Public Administration of Private Donations in Hellenistic Greece", in O.M. van Nijf and R. Alston (eds.), Political Culture in the Greek City after the Classical Age (Leuven-Paris-Walpole 2011) $119-120$.

58. Chaniotis, "Public Subscriptions" (see n. 56) 91-95.

59. Ibid. 89-93.

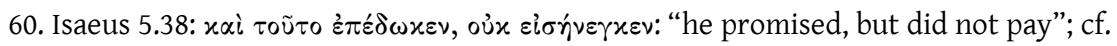
Migeotte, Souscriptions (see n. 56) 54; Chaniotis, "Public Subscriptions" (see n. 56) 93; V. Gabrielsen, Financing the Athenian Fleet: Public Taxation and Social Relations (Baltimore 2010, reprint of the first edition, Baltimore 1994) 200.

61. Cf. B. Laum, Stiftungen in der griechischen und römischen Antike: ein Beitrag zur antiken Kulturgeschichte (Leipzig-Berlin 1914) 39, no. 34. On the egdaneismos: Harter-Uibopuu, "Money" (see n. 57) 119-139, esp. 124. I. Arnaoutoglou, "Cultural Transfer and Law in Hellenistic Lycia: The Case of Symmasis Foundation", in B. Legras (ed.), Transferts culturels et droits dans le monde grec et hellénistique (Paris 2012) 205-224. 
lawful beneficiary/-ies of the donated capital, as it would have come from the interest. The lending of capital on a certain interest in reality constitutes one of the most common ways to provide the money needed for fulfilling the purpose of many private donations in Hellenistic cities, widely known as "foundations" or "trust funds" foundation. ${ }^{62}$ In such cases, there were normally public resolutions describing the deeds of the donation, accepting the donation on behalf of the beneficiary - normally the city, a sanctuary or even a private association - and providing instructions for the exact conditions and the public officers or the especially appointed officials (epimeletai) responsible for the administration (epimeleia) of the capital. ${ }^{63}$ In contrast, the resolution of the hypostoloi mentioning Kriton's donation provides no information on the deeds of the donation, the office holders in charge of the administration of the capital, the penalty clauses in the case of failed administration - a fact that leaves a series of important questions open regarding the nature and the character of the economic transactions related to the Sarapieion; these would have been obviously parts of another/other regulation/(-s).

Who was the beneficiary of the money donated? The city of Demetrias who held the official administration of the civic Sarapieion or the private association of the hypostoloi who actively participated in the cult ceremonies? Were they equally responsible for the administration of the money donated by Kriton for cult purposes? Furthermore, by whom was the egdaneismos of the money to be carried out? By the regular or the especially appointed officials of the public administration? By the officials of the hypostoloi themselves? Did they have in reality such corporate organization? And if they did, were they authorized by the state to be involved in the economic transactions of a public cult building?

The ability of the hypostoloi to bring forward and ratify a proposal in order to honour the official priest of Sarapis for his euergetism indicates the importance of the group within the local community and hints at their direct involvement in the administration of the donation. Although the text provides no further information on elected officials belonging to the association, there is evidence from other cities, for example Maroneia, about office holders belonging to the administration

62. Harter-Uibopuu, "Money" (see n. 57) 119-139, esp. 124. Arnaoutoglou, "Cultural Transfer" (see n. 61) 205-224.

63. For example, IG IV 841, 11. 14-15 (Kalaureia, late third century BC): $̇ \pi[\mu \mu \varepsilon] \mid \lambda \eta \tau \dot{\alpha} \varsigma \varkappa \alpha \tau \alpha-$ $\sigma \tau \tilde{\alpha} \sigma \alpha \iota$. The Foundation of Agasikles and Nikagora. Cf. Harter-Uibopuu, "Money" (see n. 57) 119-139, esp. 125-126. 
Isiac Cults, Civic Priesthood and Social Elite in Hellenistic Demetrias (Thessaly)

of associations related to Isiac cults. ${ }^{64}$ However, there is no evidence that they were involved in the administration of funds entrusted to the local Sarapieion. On the contrary, an inscription from Tanagra $(88-85 \mathrm{BC})$, which attests to the victory list of the local Sarapieia is followed by the apologiai of the members of the commission charged with the administration of a private fund. In this case, the agon of the Sarapieia was paid for from the interest generated by the fund. Since there is no reference to public magistrates, A. Schachter argued that those officials belong to the corporation, who ran the cult and at the same time had undertaken the administration of private donations.$^{65}$ The hypostoloi of Demetrias could have acted in the same manner.

Moreover, the evidence from the Delian public Sarapieion indicates the accumulation of money from donations made in the sanctuary and we may think of its eventual exploitation by the authorities responsible for it. ${ }^{66}$ It is widely known that Delos was famous in the Hellenistic period for the banking transactions, also under private initiative, taking place in the sanctuary of Delian Apollo.$^{67}$ Regarding the role of the associations related to the Delian Isiac cults, one cannot fail but notice the presence of their wealthy members who jointly contributed significant amounts of money in cult purposes ${ }^{68}$ Noteworthy is also that one Delian synodos of melanephoroi honoured an Athenian civic priest in the Isiac cults for being 'their own benefactor'. ${ }^{69}$

All the aforementioned evidence hints to the subtle and also vital role that private associations played in the economic affairs of the Hellenistic civic Sarapieia.

64. IThracAeg 183, 1l. 7-8 (RICIS Suppl. 114/0203) (Maroneia, 2nd cent. BC): oi $\theta \varepsilon p \alpha \pi \varepsilon u \mid \tau \alpha i$

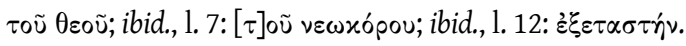

65. A. Schachter, "Egyptian Cults and Local Elites in Boiotia", in L. Bricault, M.J. Versluys and P.G.P. Meyboom (eds.), Nile into Tiber. Egypt in the Roman World. Proceedings of the IIIrd International Conference of Isis Studies, Leiden, May 11-14 2005 (Religions in the Graeco-Roman World 159, Leiden-Boston 2007) 364-391.

66. Cf. Bruneau, Recherches (see n. 13) 457-466.

67. G. Reger, "Hellenistic Greece and Western Asia Minor", in W. Scheidel, I. Morris and R. Saller (eds.), The Cambridge Economic History of the Greco-Roman World (Cambridge 2008) 473.

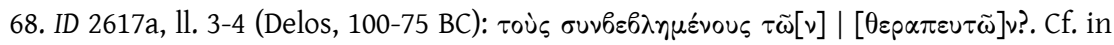
detail, in L. Migeotte, "Les souscriptions dans les associations privées", in P. Fröhlich and P. Hamon (eds.), Groupes et associations dans les cités grecques (IIIe siècle av. J.-C. - IIe siècle apr. J.-C.) (Geneva 2013) 120-121.

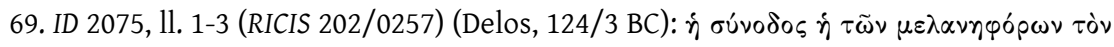

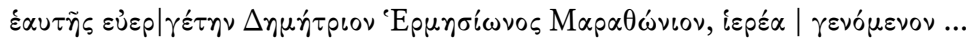


This is supported by the case of the Sarapieion in Demetrias, where the local hypostoloi are "allowed to enjoy for ever the appropriate benevolence" (1l. 17-18) - in every way that it might be - of Kriton's material benefaction to the sanctuary. It is also proposed by recent studies on private associations that have already pointed out interactions established between private associations and the public administration of the Hellenistic poleis. ${ }^{70}$ In such cases, shared administration could surely highlight the social prestige of both civic benefactors and private associations.

\section{The civic priest: Kriton, son of Kriton}

Kriton, son of Kriton, as priest of Sarapis and benefactor of the Isiac cults in Demetrias, besides the honours he received from the Isiac association of hypostoloi, was contemporaneously honoured also by the polis of Demetrias, "because of his virtue (arete) and benevolence (eunoia) towards the city". ${ }^{71}$ This honorific inscription was engraved on a stone base that most probably supported an honorific statue erected in his honour, which would have been prominently displayed in a public space of the city. At the same time and in a similar manner, a Kriton, son of Kriton, was equally honoured by the federal members of the Magnesian Koinon "for having served as common strategos of the Magnetes, because of his virtue (arete) and benevolence (eunoia) towards them". ${ }^{72}$ There is almost no doubt that the text adorned another honorific statue erected for the same person in the civic space of Demetrias. The two aforementioned statue bases - both today considered lost were not found in situ, as they were used as building material in the fortification

70. For example, I. Arnaoutoglou, " 'Ils étaient dans la ville, mais tout à fait en dehors de la cité'. Status and Identity in Private Religious Associations in Hellenistic Athens”, in O.M. van Nijf, R. Alston and C.G. Williamson (eds.), Political Culture in the Greek City after the Classical Age (Leuven-Paris-Walpole 2011) 27-48.

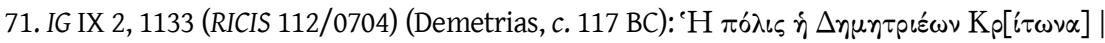

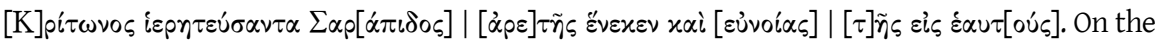
identity of the priests of Sarapis: B. Dignas, "Greek Priests of Serapis?", in B. Dignas and K. Trampedach (eds.), Practitioners of the Divine, Greek Priests and Religious Officials from Homer to Heliodorus (Washington 2008) 73-88. On priests and civic authorities, Marietta Horster and Anja Klöckner (eds.), Civic Priests. Cult Personnel in Athens from the Hellenistic Period to Late Antiquity (Religionsgeschichtliche Versuche und Vorarbeiten 58, Berlin-Boston 2012); eaed. (eds.), Cities and Priests. Cult Personnel in Asia Minor and the Aegean Islands from the Hellenistic to the Imperial Period (Religionsgeschichtliche Versuche und Vorarbeiten 64, Berlin-Boston 2013).

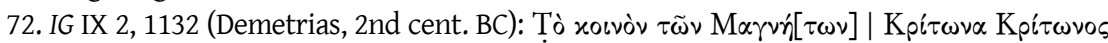

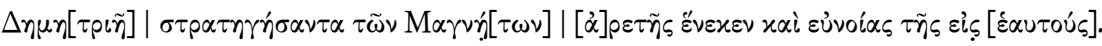


Isiac Cults, Civic Priesthood and Social Elite in Hellenistic Demetrias (Thessaly)

walls of the nearby site of Palaia/Kastro of Volos, thus their original positioning cannot be reconstructed. Still it is reasonable to assume that they would have originally been set as free-standing monuments in the agora or other public areas of the second-century BC city of Demetrias. ${ }^{73}$ Furthermore, supplementary evidence for Kriton, son of Kriton, is offered by an almost contemporary federal decree, which is dated after his official appointment as strategos of the Magnesian Koinon. ${ }^{74}$

The last two inscriptions provide the ethnic of Kriton, thus we learn that he is a citizen of Demetrias, the most prominent among the communities of the Magnesian Koinon. Situated on the bay of the biggest Thessalian natural port, second century BC Demetrias hosted the administration of the Koinon. ${ }^{75}$ Also, they bear evidence of the fact that, apart from the appointment of Kriton to the civic priesthood of Sarapis in Demetrias, he is in every probability the same person who had held the office of strategos - the most prominent position in the official federal administration of the Magnesian cities.

Following this reasoning, a citizen of Demetrias and civic priest of the cult of Sarapis, which had its seat in his mother city - a city renowned for its cosmopolitan character due to its mixed-resident community -, and a local benefactor with a considerable record of donations in the local Isiac cults and benevolent attitude towards the local private associations, as well as prominent federal officer, Kriton, son of Kriton, surely was an eminent member of the local wealthy Greek elite. His public actions, supporting both private and public interests within the local civic and federal context, as well as his religious and civic duties, made him an exemplary citizen of Demetrias and a distinguished member in the eyes of the local multicultural society.

A further question concerns us to how the full profile of such a prominent member of the local society and wealthy benefactor was represented. According to the reasoning of the hypostoloi's decree, Kriton, the civic priest of Sarapis - apart from the act of contributing to Isiac cult affairs - is also being honoured by the hypostoloi for his "eagerness", "philotimia", "magnificence", "willingness", as well as for his "virtuous" and "benevolent character" towards the Isiac association and his "piety" towards the Gods. At the same time, the polis of Demetrias and the local

73. A. Wilchelm, "Inschriften aus Thessalien", MDAI 15 (1890) 301-302.

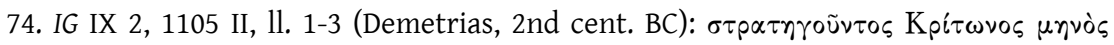

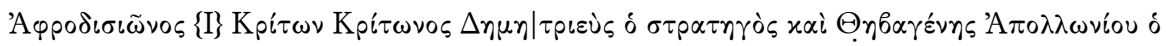

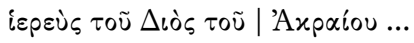

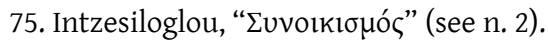


federal Koinon honoured him for his "virtue" and "benevolence" towards them. In general, the qualities of "virtue" and "benevolence" were widely employed in the praising of all kind of Hellenistic benefactors and, as A. Chaniotis recently demonstrated, emotional qualities related to pure mind, such as virtue, were given a central role in the religious doctrines of the Hellenistic societies. ${ }^{76}$ This is also indicated by contemporary eschatological beliefs praising the pious individuals who had likewise the right to gain the eternal life by entering the "chambers of Persephone". ${ }^{77}$

The idea of eternity played equally a central role in the Hellenistic honorific habit. The decree of the hypostoloi in Demetrias quotes Kriton's "desire to make his

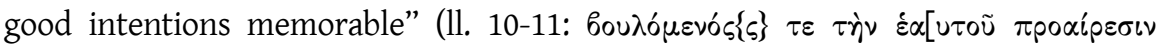
$\alpha \dot{\alpha}(\mu \nu \eta \sigma \tau o v)$, while another private foundation from Gytheion illustrates the donator's desire to make his donation "memorable to eternity (athanaton)". ${ }^{78}$ These attitudes perfectly illustrate contemporary trends in the dynamics of honorific selfpresentation and the construction of eternal fame in a Hellenistic city, in which are jointly implicated private wealthy individuals, private associations and public administration. These trends are also reflected in contemporary visual culture - for example, the great interest that was developed in the erection of honorific statues of the wealthy benefactors in prominent places of both civic and sacred nature in the Hellenistic poleis. ${ }^{79}$ More specifically, in the case of the Hellenistic Sarapieia, the presence of private benefactors is perfectly sanctioned by the nature of the cult devoted to the Isiac deities. Sarapis and Isis, healing deities of the human body and soul, saviours and benefactors of humanity themselves, had gained a prominent place in the religious and ideological beliefs of the mixed-resident cosmopolitan communities of the Hellenistic oecumene..$^{80}$

Finally, regarding the familial background of a wealthy benefactor of the Isiac cults in Demetrias, a recently discovered part of a large-scale stone monument, in

76. A. Chaniotis, "Greek Ritual Purity. From Automatisms to Moral Distinctions", in P. Rösch and U. Simon (eds.), How Purity is Made (Wiesbaden 2012) 123-139.

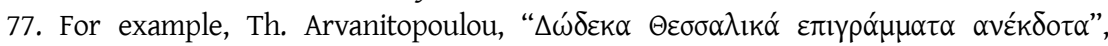

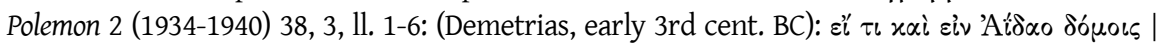

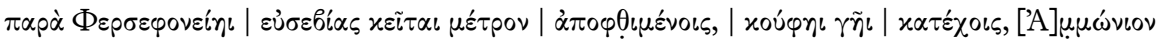
viź $\alpha\left|\Phi_{\iota} \lambda i \pi \pi \circ u\right|$.... "If in a way exists, in the House of Hades, before Persephone, a measure of piety for the deceased, you could cover, light earth, Ammonios, the son of Philip ...".

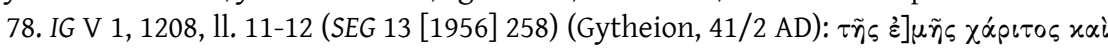
$\delta \omega \rho \varepsilon \tilde{\alpha} \varsigma \dot{\alpha} \theta \dot{\alpha} v \alpha \tau \alpha \pi \rho \circ \sigma\left[\gamma^{\prime}(v \eta] \mid[\tau \alpha \iota\right.$ x $\varepsilon \dot{\rho} \delta \eta]$.

79. J. Ma, Statues and Cities. Honorific Portraits and Civic Identity (Oxford 2013), esp. 67-109.

80. Bricault, Cultes isiaques (see n. 12) 96-101. 
the form of an exedra, which was also located - in third use - at Palaia/Kastro of Volos, bears two fragmentary votive inscriptions that can be dated, on the basis of the letter forms, to the second century $\mathrm{BC} .{ }^{81}$ The stone also bears - on second use a fragmentary manumission record dated to the Imperial period. Although fragmentary, one of the votive inscriptions mentions the name of the dedicator, "Kriton", whereas only part of the patronymic is visible in the second one, which could be reconstructed as "son of Kriton". Also, both dedications were made for members of the family of the dedicator(-s), a fact that also indicates this was a family monument. The shape of the stone, as well as the presence of the postdated manumission record, remind us of the large exedra that was found in second use in the basilica of Damokratia, near the agora of Roman Demetrias. Although this is a tentative suggestion, since the stone is actually under examination pending its publication, it seems almost certain that the second-century inscription mentioning a certain Kriton belongs originally to Hellenistic Demetrias. ${ }^{82}$ It should be noted that the site of Palaia/Kastro of Volos, which is tentatively identified with Classical Iolkos, has not yielded so far local public monuments dated to the Hellenistic period. ${ }^{83}$ It is therefore quite probable, judging also by the letters' date, that the newly discovered dedicant(-s), named Kriton, could be identified with the civic priest of Sarapis and strategos of the Magnesian Koinon and/or a member of his family (father or son). In addition, according to the inscriptions the dedicated statues depicted members - among them a woman (priestess?) - belonging to the same family. Therefore, this family monument obviously constructed under private initiative - originally promoted the social position of one of the wealthiest and more prominent families resident in second-

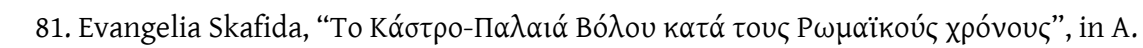
Mazarakis-Ainian (ed.), Proceedings of the Third Archaeological Work in Thessaly and Central Greece, Volos 12.3-15.3 2009 (Volos 2012) 367, fig. 3.

82. Sofia Kravaritou and Evangelia Skafida, "New Inscriptions from Palaia/Kastro of Volos" (in preparation). Stone exedra in Demetrias: P. Marzolff, "Eine verschwundene Monumentengruppe", in S.C. Bakhuizen, F. Gschnitzer, Chr. Habicht and P. Marzolff (eds.), Die deutschen archäologischen Forschungen in Thessalien. Demetrias V (Bonn 1987) 49-61.

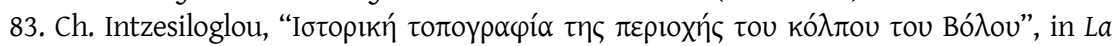
Thessalie. Quinze années de recherches archéologiques, 1975-1990. Bilans et perspectives. Actes du

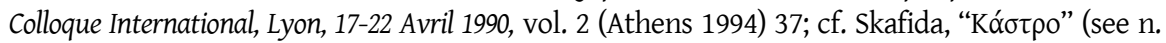
81). Lately, B. Helly ("Recherches sur les stèles funeraires de Demetrias", BCH 136-137 [20122013] 190-198, esp. 195) suggested that a Hellenistic family monument of the exedra type, parts of which are also located at Palaia/Kastro of Volos, was originally erected in the local sanctuary of Artemis Iolkia. 
century BC Demetrias. The fact that a member of such a family held the priesthood at the civic Sarapieion, and not in another poliadic sanctuary, indicated how integrated were the Isiac cults in second-century Demetrias.

\section{Magnesian Koinon and social elite: the dynamics of euergetism in second-century Demetrias}

Although the presence of local and very active elites of the Imperial period in the cities of the Eastern provinces has long been in the forefront of scientific debate, there have been no equal efforts to present evidence on the rise of members of the local elite, who after the decline of the royal power, eloquently pursued euergetic behaviour towards cult and other public matters in Hellenistic cities of mainland Greece. For example, it has been already demonstrated that in cities like Athens and those of Boeotia, prominent members of these communities held one or sometimes more priestly or other eponymous offices within a sole city. It comes as no surprise that these individuals were often honoured by civic or religious bodies in recognition of their euergetism towards local communities. ${ }^{84}$

In Demetrias, apart from Kriton, son of Kriton, who was honoured by private and public initiatives for his benefactions towards the Isiac cults and his virtue and benevolence towards the local Isiac associations as well as the polis of Demetrias and the Magnesian Koinon, contemporary epigraphic evidence brings forward other prominent members of the local society, who also held one or more of the official magistracies and equally pursued euergetic behaviour towards public matters. For example, many of the resolutions and honorific decrees of the Magnesian Koinon paid likewise honours to its own high officials. Some of the individuals who received these honours were appointed both to political and religious offices and obviously belonged to the local political and economic elite. Such is the case, for example, of Hermogenes, son of Adymos, the secretary of the Koinon, who was honoured (130-126 BC) by the federal corporation of the Magnesians "for his virtue and benevolence towards them". ${ }^{85}$ The honorific resolution also quotes the presence of Adaios, son of Adymos, who held contemporaneously the eponymous office of

84. Chr. Habicht, Studien zur Geschichte Athens in hellenistischer Zeit (Göttingen 1982); Schachter, "Egyptian Cults" (see n. 65) 364-391; see lately, with detailed bibliography, A. Chaniotis, "Illusions of Democracy in the Hellenistic World" in Athens Dialogues E-Journal (http://athensdialogues.chs.harvard.edu/cgibin/Webobjects/athensdialogues.woa/wa/d ist?dis=43) (last accessed at 24/04/2014).

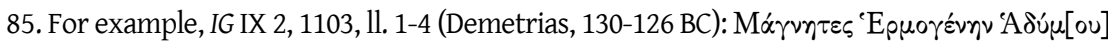

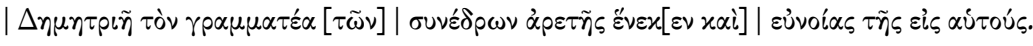


Isiac Cults, Civic Priesthood and Social Elite in Hellenistic Demetrias (Thessaly)

Zeus Akraios, one of the three tutelary deities of the Koinon. ${ }^{86}$ The shared patronymic between Hermogenes and Adaios is a potential indication of them being brothers or they could belong to the same prominent family of Demetrias, whose members held official magistrates. Furthermore, according to the same inscription, Thebagenes, son of Apollonios, held the office most probably of the nomophylax in Demetrias, while another contemporary second century $\mathrm{BC}$ decree quotes his presence as holder of the eponymous priesthood of Zeus Akraios in the Koinon..$^{87}$

Also, during the period 130-126 BC, the citizen of Demetrias Lysias, son of Epiteles, was appointed strategos of the Magnesian Koinon and was therefore honoured by the local demos of Spalauthra "for his virtuous character and benevolent attitude towards the demos"; $; 8$ in addition, Lysias is also mentioned in a contemporary decree, this time as holder of the eponymous priesthood of Zeus Akraios. ${ }^{89}$

Moreover, during also the period 130-126 BC, Demetrios, son of Aitolion, was a member of the board of magistrates (synarchia) who proposed in Demetrias the bestowal of honours upon the local strategoi and nomophylakes..$^{90}$ In addition, Demetrios held also the prestigious office of the strategos of the Koinon who, in another second century $B C$ federal resolution, decided to pay honours to him for his benevolent attitude towards ethnic disputes. ${ }^{91}$ Finally, according to a new resolution issued by the Koinon and dated to the last two decades of the second century BC, the office of strategos is held this time by Aitolion, son of Demetrios, who was in all probability the son of the above-mentioned strategos. ${ }^{92}$ If this identification is correct, then the federal office of the strategos was twice held by two members of the same family and most importantly a father and a son. This

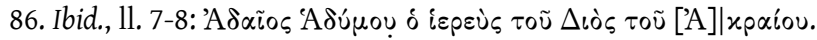

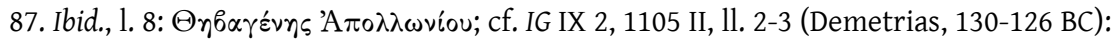

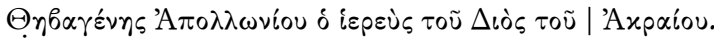

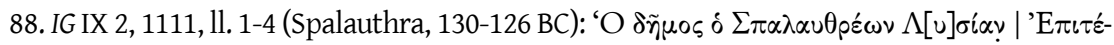

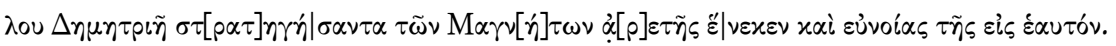

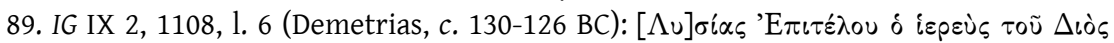

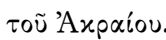

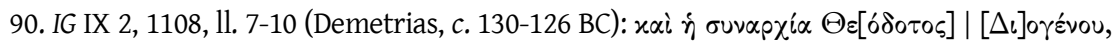

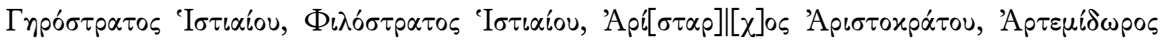

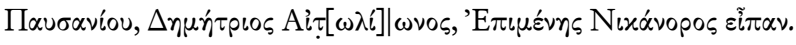

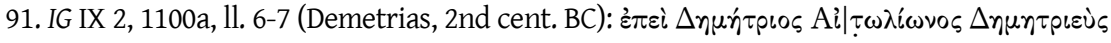

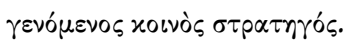

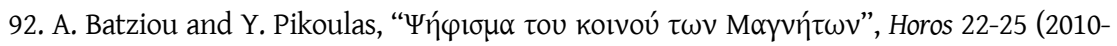
2013) $343-350$. 
would bear evidence for the hereditary character of many supreme public offices - including priestly duties - shared among members of the same family in Hellenistic Demetrias.

Under this light, local honorific attitude was equally displayed through private initiative, and more particularly by family members when dedicating statues in honour of close relatives who held priestly offices in the local traditional poliadic cults which revived in second century Demetrias (Artemis Pagasitis, Aphrodite Neleia, etc.). ${ }^{93}$

To sum up, it is obvious that the prestigious civic and religious offices in the region were conjointly held and shared by members of some prominent and probably wealthy families - a fact that created hereditary public offices, which were obviously based on wealth and its public display through euergetic acts towards the local communities.

These large-scale euergetism procedures must surely have taken place alongside the significant reorganization of the urban and sacred landscape of Demetrias that took place from the last quarter of the second century $\mathrm{BC}$ onwards. Archaeological evidence indicates a major destruction of the urban settlement of Demetrias around $120 \mathrm{BC}$, ascribed to natural causes. This occasioned the abandonment of the whole area adjacent to the ex-Macedonian royal residence, along with the "sacred agora", as well as the eventual shift of the occupation of the city towards the northern sector, close to the harbour. ${ }^{94}$ Obviously, this reorganization of urban space eventually led to the redefinition of local sacred space, including the relocation of older cults - for example, Artemis Iolkia abandoned its original seat in the Hellenistic "sacred agora" and was relocated elsewhere in Demetrias. At the end of the second/beginning of the first century $\mathrm{BC}$, a decree by the Koinon instructing the restoration of the extra-urban oracle of Apollo Koropaios equally points to cult renovation obviously related to the local socio-political texture. ${ }^{95}$ The preamble states the reasons for the desired eukosmia (the piety of the polis towards the divinity, the venerable age of the oracle which was itself held in high esteem by the polis' ancestors as well as the great number of its foreign visitors, xenoi) confirm both the

93. IG IX 2, 1123 (Demetrias, 2nd cent. BC): $\Delta u v \alpha \tau i \varsigma \zeta ~ M \varepsilon \lambda \alpha \nu \theta i ́ o v ~ ' A \rho \tau \varepsilon ́ \mu \iota \delta \iota ~ \prod \alpha \gamma \alpha \sigma i \tau \iota \delta$

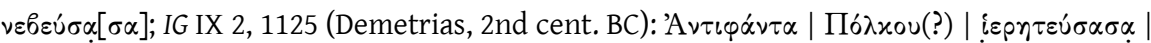

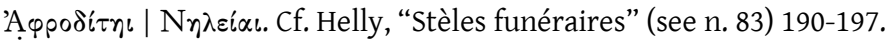

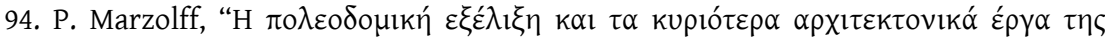

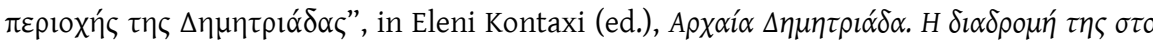

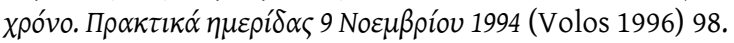

95. IG IX 2, 1109, 1l. 1-94 (Korope, end of 2nd cent./beginning of the 1st cent. BC). 
Isiac Cults, Civic Priesthood and Social Elite in Hellenistic Demetrias (Thessaly)

continuous respect for ancestral heritage and the adaptation of sacred space to present needs. ${ }^{96}$ Prohibition against violation of sacred property is prescribed for the citizens (politai), other residents (metoikountes), and passing foreigners (endemountes xenoi), which illustrates the wide and diversified range of visitors. ${ }^{97}$ Among them we should also include the individuals with Greek names originating from Italy and the Roman officials, soldiers and private individuals, who were added to the sociopolitical frame of Thessaly already from the second century BC. ${ }^{98}$

Some of these foreign individuals would have surely contributed to the development of Demetrias' new urban and sacred space and then become subjects of local honorific attitude. For example, towards the end of the second century BC, the Magnesian Koinon honours a Roman individual for benevolent attitude towards the city. ${ }^{99}$

Later on, during the first century BC, epigraphic material conveys evidence on members of the local Greek elite in Demetrias, honouring Roman officials as benefactors. ${ }^{100}$ For example, a stone base, which was not found in situ, belongs to the honorific statue of Gnaeus Pompeius (probably erected on his passage during the war against the pirates). ${ }^{101}$ Also another stone base, which originates from the northern sector of Demetrias, belongs to the bronze statue erected for C. Caelius Rufus, identified as a political senatorial adversary of Julius Caesar. ${ }^{102}$ On top of voting public honours, the Magnesians - along with the Thessalians - also

96. IG IX 2, 1109 I, 11. 13-17 (Korope, end of 2nd century/beginning of the 1st century BC):

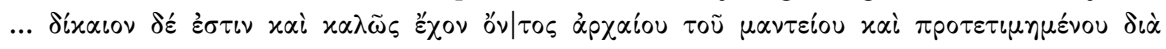

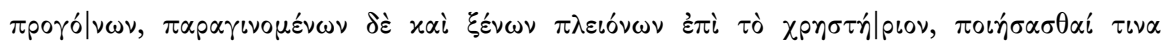

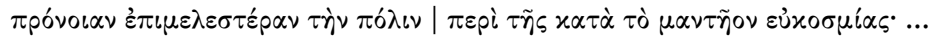

97. IG IX 2, 1109 II, 11. 79-81 (Korope, end of 2nd cent./beginning of the 1st cent. BC): ...

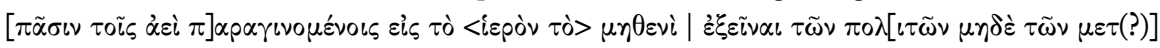

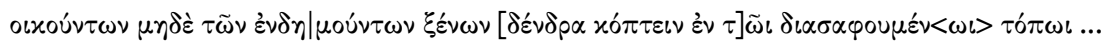

98. Helly, "Italiens" (see n. 1) 361.

99. IG IX 2, 1105 III (Demetrias, end of 2nd cent. BC).

100. Cf. Maria Kantirea, Les dieux et les dieux augustes. Le culte impérial en Grèce sous les Julio-claudiens et les Flaviens : Études épigraphiques et archéologiques (Meletemata 50; Athens 2007) 27-32.

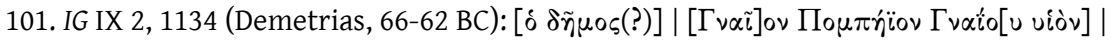

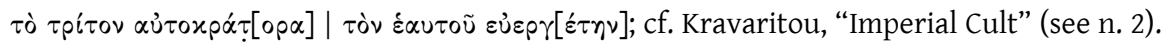
On Greek honorific attitude towards Gnaeus Pompeius, see Kantirea, Dieux (see n. 100) 32.

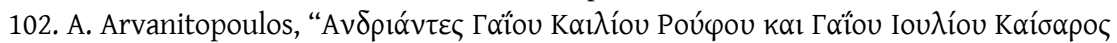

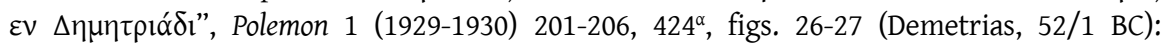

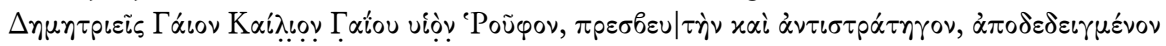

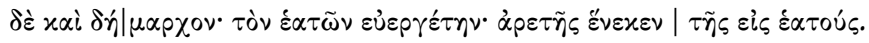


provided support to the Roman expeditions and civil wars. ${ }^{103}$ Magnesian support, Roman benefactions and Magnesian repayment of honours by the local elite are illustrated in the actions of euergetism and show the dynamic development of benefaction towards the end of the Hellenistic period. ${ }^{104}$

In that particular moment, the rising and dynamic development of actions underlining the social prestige of the local socio-political elite marked the period after the dawn of royal euergetism - directed also towards cult matters - in Demetrias in $168 \mathrm{BC}$, a period that points to the transformation of local society and may be seen in anticipation of the upcoming Roman Imperial benefactors. ${ }^{105}$ From the late second century $\mathrm{BC}$ onwards, the coexistence of honorific monuments dedicated to both Roman and Greek local benefactors in the city's civic space illustrates the changes that local society underwent and the need of the powerful elites to promote both themselves and their Roman "saviours" in public. Therefore, beyond the sector of the ex-basileion of royal Demetrias, members of the local elite e.g. civic priests, eponymous archons of the Koinon, etc. - as well as foreign benefactors were acting and eventually honoured along with traditional deities of the region, updated Isiac and other Anatolian divinities, within a newly formed urban, political, sacred and eventually social landscape that led the way to the transformation of Demetrias from a Hellenistic royal basileion to a city of the Roman East. ${ }^{106}$ Into this context, the particular devotion to the Isiac cults and their administration made a key factor for the integration of the latter in second century $\mathrm{BC}$ Demetrias and the dynamic development of the local socio-political agents. ${ }^{107}$

Sofia Kravaritou University of Oxford Faculty of Classics sofia.kravaritou@classics.ox.ac.uk

103. Helly, "Thessalie" (see n. 1) 48.

104. Cf. Kantirea, Dieux (see n. 100) 25.

105. Cf. Kravaritou, "Imperial Cult" (see n. 2).

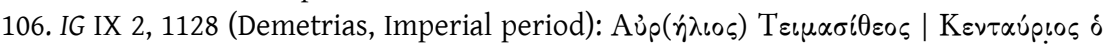

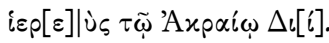

107. On the dynamics of the Isiac cults regarding the construction of socio-political power, cf. L. Bricault and M. J. Versluys (eds.), Power, Politics and the Cults of Isis. Proceedings of the Vth International Conference of Isis Studies, Boulogne-sur-Mer, October 13-15 2011 (Religions in the Graeco-Roman World 180, Leiden-Boston 2014) esp. chapters 4-8. 
Isiac Cults, Civic Priesthood and Social Elite in Hellenistic Demetrias (Thessaly)

\begin{abstract}
In second century $\mathrm{BC}$, following the decline of the Macedonian power and the abandonment of Demetrias by its royal masters, many significant socio-political changes took place in the region of eastern coastal Thessaly, such as the arrival of the Romans, the revival of local independent communities following the creation of the Magnesian Koinon, as well as the reconstruction of the civic and sacred space of Demetrias. Also, royal euergetism towards the city and its public affairs was eventually replaced by benevolent and wealthy individuals who pursued local benefactions. The paper aims to shed light on the socio-political strategies, which emerged within this new model of civic-based euergetism that was related primarily to local cult matters. In particular, the phenomenon will be discussed in relation to Isiac cults. I will seek to examine the ways Isiac cults adapted and operated in the new political, civic and sacred space, as well as into the new social and cultural environment of the second-century community in Demetrias.
\end{abstract}




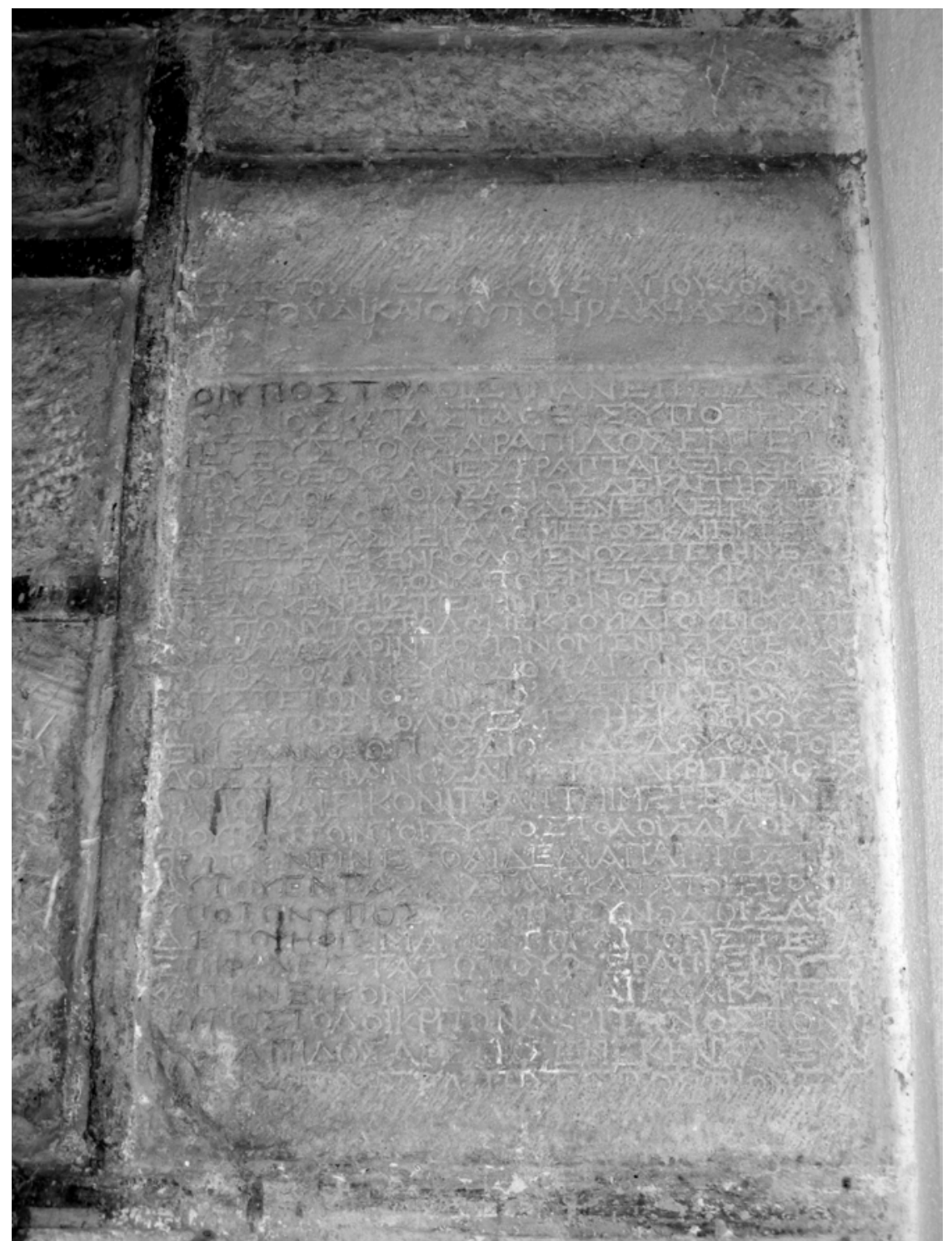

Fig. 1. The decree of the hypostoloi from Demetrias (IG IX 2, 1107b = RICIS 112/0703; c. 117 BC) in the Byzantine Church of Panagia at Makrynitsa (Photo: author, after written permission by the 13th Ephorate of Prehistoric and Classical Antiquities). 
Isiac Cults, Civic Priesthood and Social Elite in Hellenistic Demetrias (Thessaly)

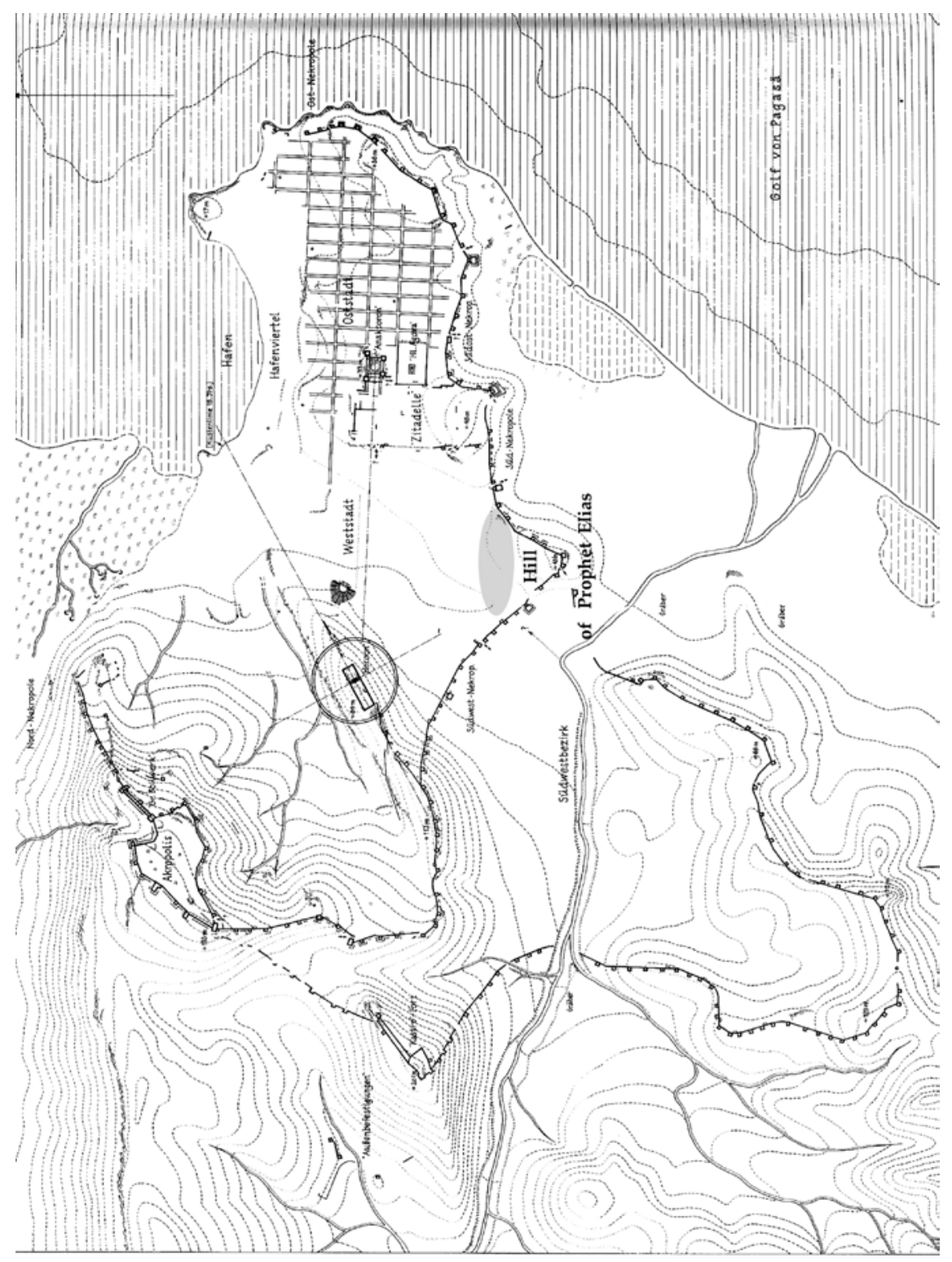

Fig. 2. Plan of ancient Demetrias with indication of the area of Arvanitopoulos excavation on the northern flank of the hill of Prophet Elias (adapted from S.C. Bakhuizen et al., Demetrias V, plan 1). 